\title{
The long-acting $\beta_{2}$-agonist salmeterol xinafoate: effects on airway inflammation in asthma
}

\author{
J.A. Roberts, P. Bradding, K.M. Britten, A.F. Walls, S. Wilson, \\ C. Gratziou, S.T. Holgate, P.H. Howarth
}

The long-acting $\beta_{2}$-agonist salmeterol xinafoate: effects on airway inflammation in asthma. J.A. Roberts, P. Bradding, K.M. Britten, A.F. Walls, S. Wilson, C. Gratziou, S.T. Holgate, P.H. Howarth. (C)ERS Journals Ltd 1999.

ABSTRACT: Salmeterol xinafoate is an inhaled long-acting $\beta_{2}$-adrenoceptor agonist recently introduced for the treatment of asthma. Both in vitro and animal studies suggest that it may have anti-inflammatory activities of benefit in this disease. To assess this directly, the effects of 6 weeks' treatment with salmeterol on indices of clinical activity, airway dysfunction and inflammation in subjects with stable atopic asthma were investigated.

In a double blind study, asthmatic patients were randomized to 6 weeks' treatment with either salmeterol $50 \mu \mathrm{g}$ twice daily $(\mathrm{n}=14)$ or placebo $(n=12)$. They underwent bronchoscopy with bronchoalveolar lavage (BAL) and bronchial biopsy immediately before starting treatment and again after 6 weeks.

Treatment with salmeterol improved clinical indices of asthma activity, but there were no changes in BAL differential cell counts or mediator levels, and no change in Tcell numbers or activation status. In the biopsy specimens there were no changes in numbers of inflammatory cells, sub-basement membrane collagen deposition or mast cell degranulation.

Regular treatment with salmeterol improves clinical indices of asthma but has no effect on the underlying inflammatory process. These findings strengthen guideline recommendations that long-acting $\beta_{2}$-agonists should not be prescribed as sole antiasthma medication.

Eur Respir J 1999; 14: 275-282.
University Medicine, University of Southampton, Southampton, UK.

Correspondence: P. Bradding

Dept of Respiratory Medicine

Glenfield Hospital

Groby Road

Leicester

LE3 9QP

UK

Fax: 441162367768

Keywords: Asthma

$\beta$-agonists

bronchial biopsy

bronchial inflammation

bronchoscopy

salmeterol xinafoate

Received: March 51998

Accepted after revision November 301998

This work was supported by a British MRC programme grant no. PG8604034 MRC and a grant in aid from Glaxo Group Research, Greenford, Middlesex, UK.
Asthma is characterized by the presence of bronchial mucosal inflammation consisting of eosinophil and mast cell infiltration and activation in both the bronchial epithelium and subepithelium [1]. This inflammatory process is present in both fatal asthma [2] and asymptomatic asthma [1], and is believed to be responsible for the clinical features of this disease.

Salmeterol xinafoate is a recently introduced inhaled long acting $\beta_{2}$-adrenoceptor agonist which produces bronchodilation for $\geq 12 \mathrm{~h}$ in asthmatic subjects [3]. In addition to its bronchodilator action, inhalation of salmeterol also prevents both the early and late reactions following allergen challenge [4], a result which has been extrapolated to suggest a possible anti-inflammatory effect. This is supported by in vitro data demonstrating that salmeterol and formoterol, another long-acting $\beta_{2}$-agonist, both inhibit immunologically stimulated histamine and leukotriene release from both human lung tissue in vitro and dispersed mast cell preparations [5]. In addition, in animal models, long acting $\beta$-agonists inhibit allergen-induced airway eosinophil recruitment and microvascular protein leakage [6]. However, no direct evidence of an airway anti-inflammatory effect in asthma is available.

Although, $\beta$-agonists provide rapid relief of asthmatic symptoms, there is concern over the safety of this group of pharmacological agents when administered regularly and over long periods to patients. This concern has arisen following publication of case-control studies from New Zealand and Canada which have linked excess $\beta$-agonist use with asthma mortality [7, 8]. In addition SEARs et al. [9] demonstrated that regular use of the $\beta$-agonist fenoterol produced poorer asthma control than "as required" treatment, while VATHENEN et al. [10] demonstrated that regular administration of terbutaline was followed by a rebound increase in bronchial hyperreactivity on cessation of treatment. A further study by vaN SCHAYCK et al. [11] has shown that regular treatment with the inhaled $\beta$ agonist salbutamol is associated with a more rapid decline in lung function than when the drug is used intermittently. Taken together this information suggests that maintained $\beta_{2}$-adrenoceptor stimulation may be harmful, and implies that the use of long-acting $\beta_{2}$-agonists could be detrimental to asthma control. Nevertheless, several studies suggest that both salmeterol and formoterol do not cause a deterioration in asthma exacerbations when prescribed for a period of 6 months to a year [12-14].

There is, therefore, great interest in the effects of regular salmeterol therapy on both symptom control in asthma and indices of bronchial mucosal inflammation. One previous study has reported that 8 weeks' treatment with salmeterol had no effect on bronchoalveolar lavage (BAL) cell profiles and activation markers in asthmatic patients, 
but these subjects were taking moderate-to-high doses of inhaled corticosteroids [15]. Thus in the presence of potent anti-inflammatory therapy, any anti-inflammatory effect of salmeterol may have been attenuated, and, equally, any adverse effect of this drug may have been masked. Furthermore, BAL data does not necessarily extrapolate to inflammatory changes in the bronchial mucosa, and does not provide data on bronchial mucosal architecture such as changes in subepithelial collagen deposition.

The authors have therefore performed a detailed bronchoscopic analysis, in a double-blind randomized placebocontrolled trial, on the effect of 6 weeks' treatment with salmeterol on symptomatic asthma control and bronchial inflammation in a group of asthmatic patients using only as-required (p.r.n.) short-acting $\beta_{2}$-agonists.

\section{Methods}

\section{Trial design}

The study was a double-blind, placebo-controlled, randomized, parallel group study design with a 2 -week "run-in" period and a 6-week treatment phase. During the initial 2 weeks, patients recorded daily in diary cards their symptoms, peak flow (morning and evening) and p.r.n. salbutamol use. At the end of this period those patients eligible for study underwent fibreoptic bronchoscopy under local anaesthesia to obtain endobronchial biopsy and lavage samples, and then commenced regular therapy for the next 6 weeks. Treatment consisted of either salmeterol 50 $\mu \mathrm{g}$ b.i.d. or matched placebo from a metered dose inhaler. Throughout this treatment period patients continued daily diary card recording of symptoms, peak flow (morning and evening) and p.r.n. salbutamol use. A second bronchoscopy was performed on the last day of the treatment phase and repeat biopsy and lavage samples obtained. Five days prior to each bronchoscopy and 5 days after completion of the trial medication, methacholine inhalation challenge was performed to monitor bronchial responsiveness. The study was approved by the Combined Hospital and University Ethical Committee and all patients gave written informed consent.

\section{Patient selection}

Patients aged $18-55$ yrs who were atopic, had a clinical history of asthma with current symptoms, and who were receiving an inhaled $\beta$-agonist p.r.n. as their sole asthma treatment were recruited for the "run-in" period. They were eligible for the treatment phase of the study if during this 2week period they demonstrated a $15 \%$ reversibility in peak expiratory flow (PEF) after inhaling salbutamol $200 \mu \mathrm{g}$, when used as rescue treatment for symptoms, and fulfilled one of the following additional criteria: 1) had a diurnal variation in PEF of $>15 \%$ on $\geq 7$ days of the run-in period, calculated on the basis of:

$$
\frac{\text { PEF previous evening }- \text { PEF next morning }}{\text { PEF previous evening }} \times 100 \%
$$

2) required symptomatic bronchodilator therapy (salbutamol) on $\geq 7$ days in the run-in period, or 3 ) had an asthma symptom score of $\geq 2$ on $\geq 5$ days of the run-in period. Symptoms were graded on a single $0-5$ scale for day- time symptoms of chest tightness, wheeze and breathlessness with $0=$ no symptoms, $1=$ symptoms for one short period of the day only, $2=$ symptoms for two or more short periods during the day, $3=$ symptoms for most of the day which did not affect normal activity, 4=symptoms throughout the day which influenced daily activity, $5=$ symptoms severe enough to prevent work and daily activities, and on a 0-4 scale for nocturnal sleep disturbance caused by chest tightness, breathlessness or wheeze, with $0=$ no sleep disturbance, $1=$ symptoms leading either to one episode of sleep disturbance or to waking early, $2=$ symptoms leading to two or more nocturnal waking episodes (including waking early), $3=$ symptoms disturbing sleep for most of the night and $4=$ symptoms so severe that they prevented sleep.

The entry criteria for patients solely receiving inhaled $\beta$ agonists p.r.n. excluded any patient who was receiving or had received within the 4 weeks prior to the run-in period inhaled or oral corticosteroids, methylxanthines, sodium cromoglycate, nedocromil sodium, oral $\beta$-agonists, anticholinergic agents or $\mathrm{H}_{1}$-antihistamines. For the purpose of the trial all patients were provided with salbutamol (100 $\mu \mathrm{g}$ per activation) to use as the relief $\beta$-agonist p.r.n.

\section{Objective measurements}

Atopy was defined as a positive skin-prick test weal response ( $\geq 3 \mathrm{~mm}$ saline control) to at least one of the following common aeroallergens: house dust mite (Dermatophagoides pteronyssinus, D. farinae), grass pollen, cat fur, and dog dander (Miles Labs Inc., Spokane, WA, USA).

PEF was recorded at home using a Mini-Wright peak flow meter. Measurements were made on rising and in the evening prior to the use of the trial medication and prior to the use of any salbutamol if required. Three separate measurements were made at each time point and recorded in the diary card with the highest value being used for subsequent analysis.

Bronchial hyperresponsiveness to methacholine was measured using an adaptation of the five-breath procedure of CHAI et al. [16] using an Inspiron mini-neb nebulizer (Bard UK Ltd, Pennywell, Sunderland, UK). Following inhalation of saline diluent, increasing concentrations of methacholine $0.03-16 \mathrm{mg} \cdot \mathrm{mL}^{-1}$ were administered at 4 min intervals until a $20 \%$ fall in forced expiratory volume in one second (FEV1) had occurred from the post-saline baseline value. The cumulative provocative concentration producing a $20 \%$ fall in FEV1 (PC20) was calculated by linear interpolation.

\section{Bronchoscopy technique}

Fibreoptic bronchoscopy was undertaken using an Olympus BF 1720 bronchoscope (Olympus Optical Co., Tokyo, Japan) under local anaesthesia as previously described [17] and in line with National Institutes of Health (NIH) guidelines [18]. Premedication consisted of nebulized salbutamol (2.5 mg) and ipratropium bromide $(0.5 \mathrm{mg})$, intravenous atropine $(0.6 \mathrm{mg})$ and intravenous midazolam (1-10 mg), titrated to achieve mild sedation. Topical anaesthesia was achieved with $4 \%$ lignocaine to the nose and oropharynx and 1\% lignocaine to the lower airways. Throughout the procedure supplemental oxygen was administered $\left(2-4 \mathrm{~L} \cdot \mathrm{min}^{-1}\right)$ and arterial haemoglobin oxygen 
saturation monitored by digital oximetry (Minolta, Heston, Middlesex, UK). BAL and endobronchial biopsy were randomly undertaken for each pair of bronchoscopies from either the right upper lobe and right middle and lower lobe carinae respectively or from the left upper lobe, lingula and left lower lobe carinae respectively. BAL was performed using prewarmed $\left(37^{\circ} \mathrm{C}\right) 0.9 \%$ sodium chloride in six-20 mL aliquots with a short $(<2 \mathrm{~min})$ dwell time. Two mucosal biopsies were taken on each occasion using alligator forceps (FB15-C; Olympus Optical Co.).

\section{Processing and analysis of lavage samples}

The BAL fluid was immediately chilled to $4^{\circ} \mathrm{C}$, transferred to a $50-\mathrm{mL}$ conical flask and the volume measured. The cells were separated by centrifugation at $400 \times g$ for 10 min at $4^{\circ} \mathrm{C}$ and the supernatant stored at $-80^{\circ} \mathrm{C}$ for subsequent measurement of mediator and albumin levels. The cell pellet was resuspended in phosphate-buffered saline (PBS) ( $\mathrm{pH} 7.4)$ and the cells counted in a haemocytometer. A $50-\mu 1$ aliquot of cells was subjected to cytocentrifugation (Cytospin; Shandon Southern, Runcorn, UK), air-dried and then stained with May-Grünwald Giemsa. Differential cell counts of lymphocytes, neutrophils, eosinophils, monocytes and epithelial cells were estimated by counting 800 cells. As mast cell numbers were low, numbers of these were assessed by employing a standard field counting technique with the equivalent of 5-20,000 nucleated cells counted.

\section{Flow cytometry}

Proportions of BAL fluid CD3+ lymphocytes expressing CD4, CD8 and the activation markers CD25 and human leukocyte antigen (HLA)-DR were analysed by flow cytometry as described previously [19]. Briefly, 50$\mu \mathrm{L}$ aliquots of resuspended cells were incubated with 20 $\mu \mathrm{L}$ of fluorescein isothiocyanate (FITC)-conjugated antiCD3 monoclonal antibody $(\mathrm{mAb})$ and $20 \mu \mathrm{L}$ of phycoerythrin (PE)-conjugated anti-CD4, -CD8, -CD25 or - HLA-DR at optimal dilutions. All mAbs were purchased from Becton-Dickinson, (Oxford, UK). Ten-thousand events were acquired using FACScan (Becton Dickinson) research software and dual colour analysis was performed using Lysis software (Becton Dickinson).

\section{Mediator assays}

BAL levels of histamine and tryptase were measured by radioimmunoassay (RIA) (Immunotech SA, Marseille, France and Pharmacia, Uppsala, Sweden respectively), according to the manufacturers instructions, and prostaglandin (PG) $\mathrm{D}_{2}$ was measured by RIA based on the method of KelLy et al. [20]. Albumin was assayed using rocket immunoelectrophoresis according to the method described by WeEKE [21].

\section{Bronchial biopsy processing and immunohistochemistry}

Biopsies for immunohistochemistry were immediately placed in ice-cooled acetone containing the protease inhibitors iodoacetamide $(20 \mathrm{mM})$ and phenylmethylsulpho- nylfluoride (PMSF) $(2 \mathrm{mM})$, stored at $-20^{\circ} \mathrm{C}$ for $24 \mathrm{~h}$ and then processed into water-soluble glycol methacrylate (GMA) resin [22].

Immunohistochemistry was undertaken in GMA-embedded tissue as described previously [22]. Briefly, 2- $\mu \mathrm{m}$ sections were cut by ultramicrotomy, floated on $0.2 \%$ ammonia solution in water for $1 \mathrm{~min}$ and dried at room temperature for 1-4 h. Sections were pretreated with a solution of $0.1 \%$ sodium azide and $0.3 \%$ hydrogen peroxide for $30 \mathrm{~min}$ to inhibit endogenous peroxidase, washed in triethanolamine-buffered saline (TBS) $(2 \times 5 \mathrm{~min})$ and then treated for 30 min with blocking medium consisting of Dulbecco's minimal essential medium (MEM), $10 \%$ foetal calf serum (FCS) and $1 \%$ bovine serum albumin (BSA). The following mouse immunoglobulin (Ig) G1 mAbs were applied for 16-20 h at previously titrated optimal dilutions: UCHT1 to CD3 for pan T-cells (Dako Ltd, High Wycombe, UK); anti-CD4 (Becton Dickinson) and -CD8 (Dako Ltd) for the CD4+ and CD8+ T-cell subsets respectively; AA1 to mast cell tryptase [23] (A. Walls, Southampton University, Southampton, UK); and EG2 to the cleaved form of eosinophil cationic protein (ECP) in activated eosinophils (Pharmacia, Milton Keynes, UK). After washing $(3 \times 5 \mathrm{~min})$, bound antibodies were labelled with biotinylated rabbit anti-mouse $\mathrm{F}\left(\mathrm{ab}^{\prime}\right)_{2}$ fragments (Dako Ltd) for $2 \mathrm{~h}$, washed and detected using streptavidin-biotin peroxidase complexes (Dako Ltd). After further washing, aminoethylcarbazole was applied as the chromogen giving a red reaction product, and the sections counterstained with Mayer's haematoxylin. Control slides were similarly treated but in one case excluding the primary antibody and in the other employing an unrelated antibody of the same isotype (M9269; Sigma, Poole, UK) at immunoglobulin concentrations 5-20 $\mu \mathrm{g} \cdot \mathrm{mL}^{-1}$.

\section{Electronmicroscopy}

The biopsy samples for electron microscopy were fixed in $2.5 \%$ glutaraldehyde in cacodylate buffer $(\mathrm{pH} 7.4)$ for a minimum of $4 \mathrm{~h}$. They were then post-fixed in $2 \%$ osmium tetroxide, impregnated with $1.5 \%$ uranyl acetate and dehydrated through graded ethanol. Specimens were then cleared in Histosol (Shandon Southern Products Ltd, Runcorn, Cheshire, UK) and infiltrated with Spurr's resin. Processed specimens were embedded in fresh resin and polymerized at $60^{\circ} \mathrm{C}$ for $18 \mathrm{~h}$ [24].

Initially $1-\mu \mathrm{m}$ sections were cut and stained with a rapid toluidine blue method to assess suitability for electron microscopy. Ultrathin sections $(100 \mathrm{~nm})$ were cut from suitable blocks and counterstained with Reynold's lead citrate. Sections were examined in a Hitachi H7000 electron microscope (Hitachi, Tokyo, Japan) and representative photographs were taken.

\section{Assessment and quantification of immunohistochemical staining}

The area of the submucosa and the length of overlying epithelium were calculated for each section using the Video Interactive Display System (VIDS 2) linked to AMS software (Analytical Measurement Systems, Cambridge, 
UK). Nucleated cells exhibiting positive immunoreactivity were counted and expressed as the number per square millimetre of submucosa or the number per millimetre length of basement membrane in the epithelium.

\section{Assessment of electron microscopy}

The thickness of sub-basement membrane collagen deposition was assessed using Vernier callipers (Peak Graticules, Tokyo, Japan). Mast cells and eosinophils were identified using established morphological criteria. The extent of mast cell and eosinophil degranulation was expressed as the percentage of degranulating granules present out of the total number of granules.

\section{Statistical analysis}

Symptom scores, $\beta_{2}$-agonist use and $\log \mathrm{PC} 20$ values were compared within groups using the paired Student's ttest, and between groups using the unpaired Student's ttest. Mediator levels, cell counts in BAL and bronchial biopsy specimens, and collagen thickness were expressed as medians and ranges, and were compared within groups using the Wilcoxon signed-rank test, and between groups using the Mann-Whitney U-test. Correlations were explored using Spearman's rank correlation test. The level of significance was accepted as $\mathrm{p}<0.05$.

\section{Results}

\section{Clinical data}

Twenty-six patients were randomly allocated to treatment, 14 receiving salmeterol $(\mathrm{S})$ and 12 placebo $(\mathrm{P})$. The pretreatment characteristics of the two groups did not significantly differ (table 1). Three patients failed to complete the protocol, one on placebo, who had a clinical deterioration necessitating the prescription of oral corticosteroids by their general practitioner, and two on salmeterol (one a nonattender after allocation and one who was unable to tolerate the second bronchoscopy). Paired bronchoscopy sample results and clinical data were therefore available from 23 subjects $(12 \mathrm{~S} / 11 \mathrm{P})$.

\section{Symptom and concomitant treatment monitoring}

The pretreatment recording of nocturnal symptoms, daytime symptoms and inhaled salbutamol use was similar in the two treatment groups (fig. 1). Placebo treatment had no influence on either symptom expression or $\beta_{2}$-agonist p.r.n. use (fig. 1). During the 6 weeks of placebo medica-
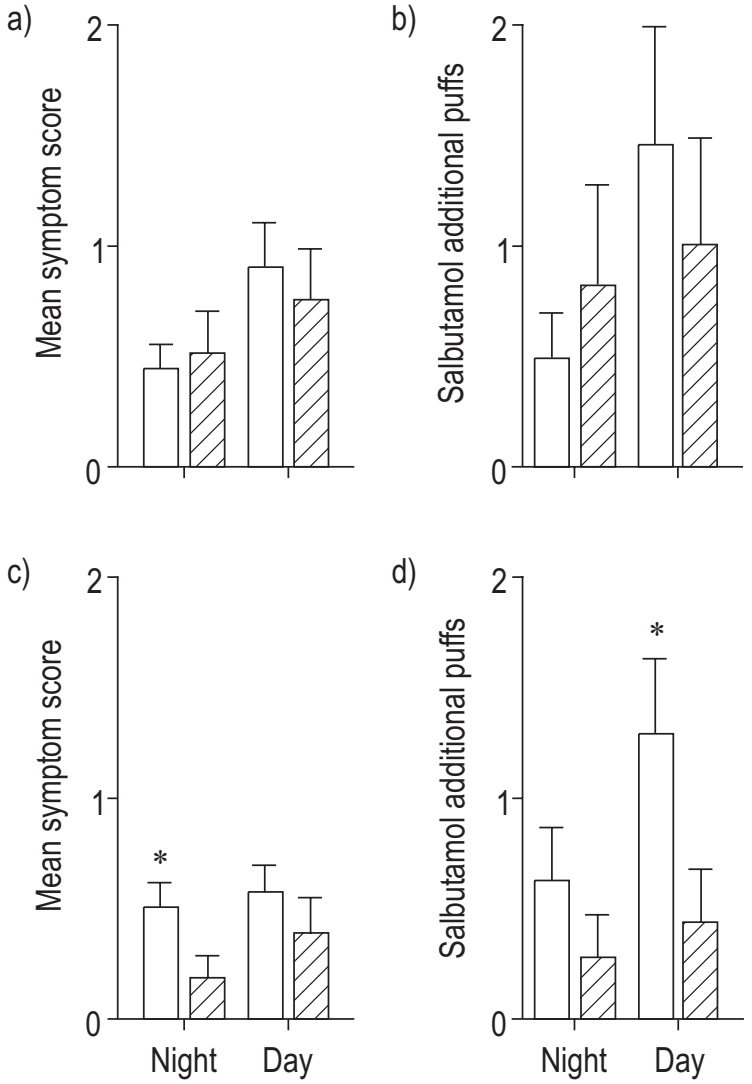

Fig. 1. - Symptom scores (a, c) and additional salbutamol use (b, d) during the run-in period $(\square)$ and the 6-week treatment $(\mathbb{Z})$ in: a, b) the placebo group; and c, d) the salmeterol group. Data are presented as mean \pm SEM. $*:$ p $<0.05$ versus 6 -week treatment.

tion there was a small but significant increase in mean morning PEF (from 419 to $442 \mathrm{~L} \cdot \mathrm{min}^{-1}, \mathrm{p}<0.03$ ) although not in mean evening PEF (from 432 to $450 \mathrm{~L} \cdot \mathrm{min}^{-1}$, $\mathrm{p}>0.05$ ) (fig. 2). In the salmeterol treated patients there was a reduction in nocturnal symptoms $(p<0.05)$ and daytime salbutamol use $(\mathrm{p}<0.04)$ (fig.1). These clinical improvements were paralleled by a highly significant increase in morning PEF (from 415 to $483 \mathrm{~L} \cdot \mathrm{min}^{-1}$, $\mathrm{p}<0.001$ ) and in evening PEF (from 417 to $483 \mathrm{~L} \cdot \mathrm{min}^{-1}$, $\mathrm{p}<0.01$ ) (fig. 2). However, when comparing changes from pretreatment to end of treatment between the two groups, only the change in morning peak flow was significantly greater $(p<0.03)$ in the salmeterol group when compared with the placebo group (fig. 2).

\section{Methacholine provocative concentrations}

The baseline PC20 values were similar in the salmeterol and placebo-treated patients, with geometric mean values

Table 1. - Characteristics of patients in each treatment group

\begin{tabular}{lccccccc}
\hline & $\begin{array}{c}\text { Patients } \\
\mathrm{n}\end{array}$ & $\begin{array}{c}\text { Age } \\
\text { yrs }\end{array}$ & $\begin{array}{c}\text { Sex } \\
\text { M/F }\end{array}$ & $\begin{array}{c}\text { FEV1 } \\
\text { L }\end{array}$ & $\begin{array}{c}\text { FEV1 } \\
\text { \% pred }\end{array}$ & $\begin{array}{c}\text { PEFR } \\
\text { \% reversibility }\end{array}$ & $\begin{array}{c}\text { PC20* } \\
\text { mg.mL } \text { m }^{-1}\end{array}$ \\
\hline Salmeterol & 14 & $30.6 \pm 1.58$ & $8 / 6$ & $3.76 \pm 0.26$ & $95.3 \pm 6.0$ & $35.6 \pm 4.7$ & $0.34(0.05-8.44)$ \\
Placebo & 12 & $32.4 \pm 2.9$ & $9 / 3$ & $3.53 \pm 0.25$ & $91.5 \pm 4.5$ & $34.2 \pm 2.5$ & $0.73(0.05-5.34)$ \\
\hline
\end{tabular}

Data are presented as mean \pm SEM. *: geometric mean (range). M: male; F: female; FEV1: forced expiratory volume in one second; PEFR: peak expiratory flow rate; $\mathrm{PC} 20$ : provocative concentration of methacholine causing a $20 \%$ fall in FEV1. 


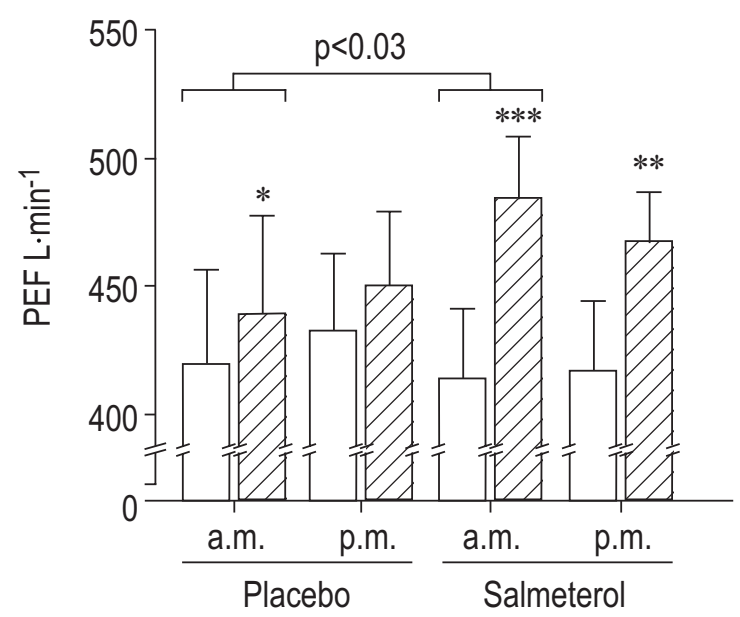

Fig. 2. - Morning (a.m.) and evening (p.m.) peak expiratory flow (PEF) during the run-in period $(\square)$ and during the 6-week treatment $(\mathscr{C})$ for the placebo and salmeterol groups. *: $\mathrm{p}<0.05 ; * *: \mathrm{p}<0.01 ; * * *: \mathrm{p}<0.001$ versus run-in.

of $0.44 \mathrm{mg} \cdot \mathrm{mL}^{-1}$ and $0.72 \mathrm{mg} \cdot \mathrm{mL}^{-1}$ respectively $(\mathrm{p}>0.05)$. Repeat measurement in the 6th week of treatment and again 5 days after discontinuation of therapy identified no change in the placebo group, with respective geometric mean values of $0.37 \mathrm{mg} \cdot \mathrm{mL}^{-1}$ and $1.04 \mathrm{mg} \cdot \mathrm{mL}^{-1}(\mathrm{p}>0.05)$. During salmeterol therapy there was a significant reduction in methacholine reactivity with the geometric mean PC20 in the 6th week of treatment rising to $1.95 \mathrm{mg} \cdot \mathrm{mL}^{-1}$ $(\mathrm{p}<0.01)$. However, 5 days following discontinuation of salmeterol therapy the group geometric mean $\mathrm{PC} 20$ value of $0.80 \mathrm{mg} \cdot \mathrm{mL}^{-1}$ did not significantly differ from the pretreatment value $(\mathrm{p}>0.05)$. The change in $\mathrm{PC} 20$ methacholine from baseline was significantly greater at 6 weeks in the salmeterol group compared to the placebo group $(p<0.001)$, but no difference was apparent between the two groups 5 days after stopping treatment $(\mathrm{p}>0.05)$.

\section{Bronchoalveolar lavage}

The mean \pm SEM percentage recovery of lavage fluid before and after placebo and salmeterol treatments were similar at $56.4 \pm 5.9 \%, 50.3 \pm 6.4 \%, 53.9 \pm 5.8 \%$ and $46.5 \pm$ $3.0 \%$ respectively ( $>0.05)$. The median cell counts in the placebo treatment group were higher pretreatment $(14.5 \times$ $10^{4}$ cells $\left.\cdot \mathrm{mL}^{-1}\right)$ than in the salmeterol treatment group $(7.5 \times$ $10^{4}$ cells $\left.\cdot \mathrm{mL}^{-1}\right)$. These differences were maintained posttreatment $\left(11.7 \times 10^{4}\right.$ cells $\cdot \mathrm{mL}^{-1}$ and $5.4 \times 10^{4}$ cells $\cdot \mathrm{mL}^{-1}$ respectively) with no treatment-related effect. The differ- ential cell counts did not differ between or within treatments (table 2).

Flow cytometric analysis of lavage T-lymphocyte subsets and activation status (CD25 and HLA-DR receptor expression) failed to reveal any differences between the treatment groups before or after therapy and no differences between the two samples within treatment groups (table 3). Lavage concentrations of the mast cell mediators histamine, $\mathrm{PGD}_{2}$ and tryptase also did not change after 6 weeks' treatment with either placebo or salmeterol treatment (table 4) with no differences within or between groups. Similarly neither placebo nor salmeterol had any effect on the concentration of albumin (table 4).

\section{Endobronchial biopsies}

Paired biopsies suitable for analysis were obtained from 15 patients (nine salmeterol and six control). The numbers of mast cells, eosinophils and T-lymphocytes before and after treatment are detailed in figure 3 . Neither placebo nor salmeterol treatment had any significant effect on the mucosal cell counts with good concordance both within the paired biopsies and between the two treatment groups (fig. 3). No effect of either treatment was identified on the depth of the sub-basement membrane collagen with median (range) values of $8.2(5.55-9.35) \mathrm{mm}$ pre- and 8.05 (7.15-12.34) $\mathrm{mm}$ postsalmeterol, and 8.23 (5.63-12.53) $\mathrm{mm}$ pre- and $10.11(8.15-14.31) \mathrm{mm}$ postplacebo. Transmission electron microscopic examination of tissue mast cells (median 4.5 cells per biopsy, range $0-10$ ) demonstrated ultrastructural features of degranulation both before and after treatment with both placebo (median number of altered granules per biopsy $68 \%$ preplacebo, $70 \%$ postplacebo) and salmeterol (median number of altered granules per biopsy $32 \%$ presalmeterol, $55 \%$ postsalmeterol). Similarly, there was no apparent effect of salmeterol on the degranulation appearance of eosinophils.

\section{Discussion}

This study demonstrates that 6 weeks' treatment in asthmatic subjects with the long-acting inhaled bronchodilator salmeterol xinafoate has no effect on measured indices of airway inflammation when assessed by the number and activation status of inflammatory cells present in mucosal biopsies and BAL fluid, and the concentration of mediators found in BAL. Despite this, salmeterol proved highly effective in relieving symptoms and improving pulmonary function including a marked reduction in bronchial reactivity while the drug was still being administered. These

Table 2. - Influence of the 6-week treatment with salmeterol or placebo on lavage differential cell counts

\begin{tabular}{ccccccc}
\hline & Macrophage & Lymphocyte & Epithelial & Eosinophil & Neutrophil & Mast Cell* \\
\hline Salmeterol & & & & & & \\
Baseline & $77.0(60.7-85.0)$ & $12.4(7.0-24.5)$ & $6.0(0.3-17.0)$ & $1.8(0.3-3.6)$ & $0.2(0.0-4.8)$ & $0.23(0.04-1.01)$ \\
6 weeks & $76.7(47.0-82.9)$ & $17.9(0.4-39.3)$ & $10.1(0.3-15.0)$ & $1.4(0.4-10.7)$ & $0.4(0.0-3.9)$ & $0.31(0.08-1.82)$ \\
Placebo & & & & & & \\
Baseline & $82.0(73.3-93.9)$ & $8.6(2.5-16.8)$ & $2.0(0.0-11.1)$ & $2.1(0.3-4.4)$ & $0.4(0.0-1.2)$ & $0.26(0.11-1.40)$ \\
6 weeks & $82.8(52.9-87.3)$ & $13.6(5.0-25.5)$ & $4.7(0.0-25.8)$ & $1.0(0.4-8.8)$ & $0.6(0.0-2.3)$ & $0.35(0.10-0.80)$ \\
\hline
\end{tabular}

Data are presented as median (range) percentage cell count. *: differential cell counts were based on counting 800 cells with the exception of mast cells for which 5-20,000 cells were counted. Salmeterol group, $n=12$; placebo group, $n=11$. 
Table 3. - Effect of 6 weeks' treatment with salmeterol or placebo on bronchoalveolar lavage T-cell subsets and their activation markers

\begin{tabular}{lcccr}
\hline & CD4 & CD8 & CD25 & HLA-DR \\
\hline Salmeterol & & & & \\
Baseline & $60.2(22.2-74.7)$ & $35.7(25.0-54.5)$ & $3.9(1.5-12.0)$ & $11.1(1.7-23.8)$ \\
6 weeks & $68.7(24.3-73.9)$ & $35.1(20.0-64.7)$ & $3.7(2.0-7.0)$ & $8.6(2.5-22.1)$ \\
Placebo & & & & \\
Baseline & $55.7(23.6-80.6)$ & $31.0(14.7-67.5)$ & $4.9(1.6-10.1)$ & $11.1(3.4-19.5)$ \\
6 weeks & $55.8(26.5-79.9)$ & $33.3(13.5-57.2)$ & $6.0(2.2-7.7)$ & $15.0(4.0-27.3)$ \\
\hline
\end{tabular}

Data are presented as median (range) percentage of CD3+ cells. Salmeterol, $n=12$; placebo $n=11$.

findings differ from those reported with the inhaled corticosteroid beclomethasone dipropionate in a similar group of patients in whom clinical and physiological improvement was paralleled by a marked reduction in airway mucosal cell infiltration and activation [25]. These results thus provide direct information with which to evaluate the airway anti-inflammatory effects of a long-acting, $\beta$ agonist and help to identify the position of this class of drug within the guidelines for asthma management [26].

$\beta$-agonists have long been used in asthma for their bronchodilator properties. However, $\beta$-adrenoceptors are present on a number of other cell types including respiratory tract submucosal glands, vascular endothelium, ciliated epithelium, mast cells, Clara cells, type II pneumocytes and cholinergic ganglia [27]. $\beta_{2}$-adrenoceptor stimulation inhibits IgE-dependent mediator release from human lung mast cells in vitro [28]. Salmeterol itself has been shown in vitro to have a sustained inhibitory effect against histamine, leukotriene $(\mathrm{LT}) \mathrm{C}_{4}, \mathrm{LTD}_{4}$ and $\mathrm{PGD}_{2}$ release from human lung fragments [5], and inhibits antigeninduced protein extravasation in both the skin and airways of guinea-pigs [6]. In addition, $\beta$-agonists produce a sustained increase in epithelial cell cilia beat frequency in vitro [29]. Theoretically all these actions could limit airway inflammation and be of clinical benefit in asthma, a disease whose airway dysfunction is dependent upon well-defined inflammatory events.

Indirect evidence for these actions in asthma has been derived from allergen-inhalation studies. Salbutamol inhibits the immediate increment in plasma histamine, suggestive of an inhibitory action on mast cell degranulation [30], while both salmeterol and formoterol pretreatment attenuates the late phase bronchoconstrictor response and associated acquisition of bronchial hyperresponsiveness [4]. This might suggest that there is inhibition of the cellular influx into the bronchial mucosa that accompanies and probably causes the late asthmatic response (LAR), or simply occur as a result of prolonged bronchodilation.
Evidence from challenge studies in guinea-pigs with allergen and platelet-activating factor (PAF) have shown that pretreatment with salmeterol inhibits the accumulation of eosinophils in the airways that occurs $24 \mathrm{~h}$ postchallenge [6].

By undertaking endobronchial biopsy and lavage before and after 6 weeks' treatment in a defined group of asthmatic patients the authors have been able to directly investigate any possible effects on the inflammatory process in relation to clinical efficacy. In contrast to allergen challenge studies, which investigate acute airway inflammation, the present study has shown no effect of continuous $\beta_{2}$-receptor stimulation on resting indices of mast cell degranulation or plasma protein extravasation. Continuing mast cell degranulation was evident both by the ultrastructural appearance of this cell type when viewed by transmission electron microscopy, and by measurement of three mast cell-derived mediators, histamine, tryptase and $\mathrm{PGD}_{2}$, in lavage fluid. This absence of effect of $\beta_{2}$-agonists on mast cell degranulation and mediator release in chronic asthma has not been described previously, and demonstrates that, in contrast to acute allergen-dependent mediator release, disease-related mast cell activation is not sensitive to this class of drugs. Whether this represents tachyphylaxis or an allergen-independent, $\beta_{2}$-resistant mechanism of release awaits further investigation.

Similarly the influence of salmeterol on airway eosinophils was monitored over the 6-week treatment period. No effect of salmeterol over placebo was identified on eosinophil recruitment assessed by cell numbers recovered in BAL or in the tissue biopsy sections. Also, eosinophil activation appeared to be unaltered when the tissue ultrastructure appearance was assessed by transmission electron microscopy. The lavage and tissue content of total lymphocytes and CD4-, CD8- and CD25+ subpopulations were also unchanged by salmeterol. This is in clear contrast to the powerful inhibitory action of inhaled beclomethasone, which, for a comparable level of clinical and

Table 4. - Effect of 6 weeks' treatment with salmeterol or placebo on mediator and albumin levels in bronchoalveolar lavage fluid

\begin{tabular}{lcccc}
\hline & $\begin{array}{c}\text { Histamine } \\
\text { nmol } \cdot \mathrm{L}^{-1}\end{array}$ & $\begin{array}{c}\text { Prostaglandin } \\
\mathrm{ng} \cdot \mathrm{L}^{-1}\end{array}$ & $\begin{array}{c}\text { Tryptase } \\
\mathrm{ng} \cdot \mathrm{L}^{-1}\end{array}$ & $\begin{array}{c}\text { Albumin } \\
\mathrm{g} \cdot \mathrm{L}^{-1}\end{array}$ \\
\hline $\begin{array}{l}\text { Salmeterol } \\
\text { Baseline }\end{array}$ & $4.6(0.5-16.4)$ & & & \\
6 weeks & $5.0(1.1-19.1)$ & $118.4(32.5-587.0)$ & $0.39(0.1-3.57)$ & $11.4(5.4-74.9)$ \\
$\begin{array}{l}\text { Placebo } \\
\text { Baseline }\end{array}$ & $2.5(1.4-27.1)$ & $49.2(2.0-200.2)$ & $0.53(0.1-6.36)$ & $20.0(5.0-70.9)$ \\
6 weeks & $2.1(1.1-42.7)$ & $31.6(5.1-653.3)$ & $0.27(0.09-1.87)$ & $15.6(3.5-57.3)$ \\
\hline
\end{tabular}

Data are presented as median (range). 
a)

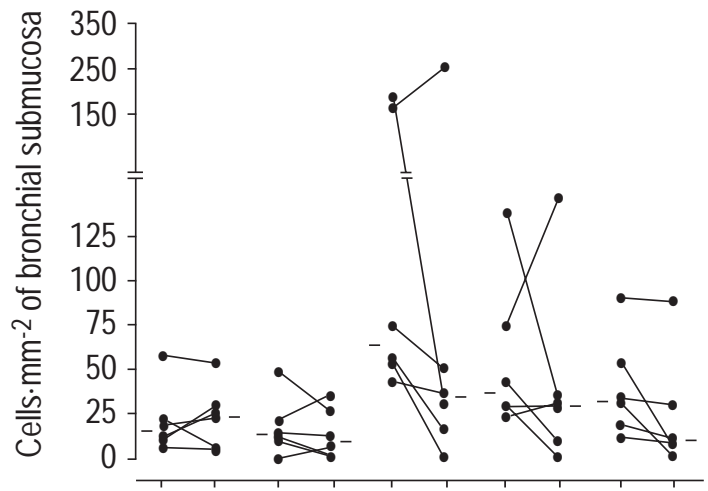

b)

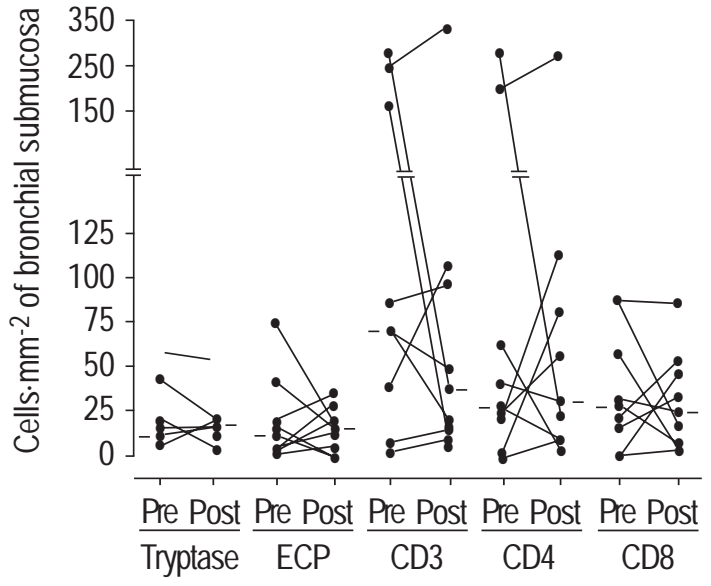

Fig. 3. - Inflammatory cell counts in the bronchial submucosa before (Pre) and after (Post): a) placebo; and b) salmeterol treatment. Medians are indicated by horizontal bars. ECP: eosinophil cationic protein.

physiological effect, profoundly reduced numbers of mast cells, eosinophils and T-cells [25].

Evaluation of bronchial biopsies to investigate pathological changes in clinical asthma has become an increasingly popular investigative tool. As biopsies are of necessity small, there is a concern that they may not be representative of the pathological processes occurring in the airway. However it has been demonstrated that biopsies from different sites within the bronchial tree of patients with asthma show similar degrees of inflammation when assessed by the number and type of infiltrating leukocytes [31]. Differential cell counts obtained from cytospin preparations of BAL showed a similar distribution of cell types reported in other studies of asthmatic patients with a preponderance of macrophages. Eosinophil numbers are increased in patients with both fatal [2] and mild [1] asthma compared to levels reported in nonasthmatic patients. In this study salmeterol did not affect eosinophil counts in keeping with the lack of effect on airway inflammation and bronchial reactivity. These observations would therefore suggest that the failure to find any effects of salmeterol on indices of inflammation were not due to methodological problems. Furthermore, the data is supported by the recent study of GARDINER et al. [15], who found no change in BAL cell profile, T-cell activation status, or albumin and tryptase concentrations after 8 weeks of treatment with salmeterol in a group of mild asthmatic subjects, although their subjects were also taking inhaled corticosteroids.

A rebound increase in bronchial hyperresponsiveness (BHR) has been reported $24 \mathrm{~h}$ after cessation of $\beta_{2}$-agonist treatment with terbutaline [10]. If this were related to downregulation of $\beta_{2}$-receptor responsiveness [32] then prolonged stimulation by salmeterol might be expected to produce a similar, or more marked rebound in BHR on cessation of treatment. However, a previous study by CHEUng et al. [33] failed to show any rebound effect on BHR 2 and 4 days after stopping 8 weeks' treatment with salmeterol in spite of demonstrating marked attenuation of its antibronchoconstrictor activity. Similarly, in the present study there was no evidence of an increase in BHR to methacholine 5 days after stopping therapy when compared to baseline values in the salmeterol treated group. The authors chose to test 5 days after stopping salmeterol to ensure that all $\beta_{2}$-agonist effect had cleared, although a clinically significant rebound should still be apparent at this time.

In summary, this study has demonstrated that salmeterol is an effective treatment for the symptoms of asthma and improves lung function as measured by morning and evening peak expiratory flow rates, but over a 6 week period has no detectable effect on a range of indices of airway inflammation. This is in contrast to the effect of inhaled corticosteroids, which in two previous studies have been shown to give a clear reduction in numbers of mucosal eosinophils, mast cells and T-cells after 6 weeks' treatment in parallel with an improvement in symptoms and airway function $[25,34]$. Because of the potential risk of masking deteriorating underlying inflammation, the current findings strengthen the recommendation that long acting $\beta_{2}$-agonists such as salmeterol should only be prescribed to asthmatic patients already receiving inhaled corticosteroids.

\section{References}

1. Djukanovic R, Roche WR, Wilson JW, et al. Mucosal inflammation in asthma. Am Rev Respir Dis 1990; 142: 434-457.

2. Dunnill MS. The pathology of asthma with special reference to changes in the bronchial mucosa. J Clin Pathol 1960; 13: 27-33.

3. Ullman A, Svedmyr N. Salmeterol, a new long acting inhaled beta 2 adrenoceptor agonist: comparison with salbutamol in adult asthmatic patients. Thorax 1988; 43: 674-678.

4. Twentyman OP, Finnerty JP, Harris A, Palmer J, Holgate ST. Protection against allergen-induced asthma by salmeterol. Lancet 1990; 336: 1338-1342.

5. Butchers PR, Vardey CJ, Johnson M. Salmeterol: a potent and long acting inhibitor of inflammatory mediator release from human lung. Br J Pharm 1991; 104: 672-676.

6. Whelan CJ, Johnson M. Inhibition by salmeterol of increased vascular permeability and granulocyte accumulation in guinea-pig lung and skin. Br J Pharmacol 1992; 105: 831-838.

7. Crane J, Pearce N, Flatt A, et al. Prescribed fenoterol and death from asthma in New Zealand. Lancet 1989; i: $917-$ 922.

8. Spitzer WO, Suissa S, Ernst P, et al. The use of $\beta$-agonists and the risk of death and near-death from asthma. $N$ Engl J Med 1992; 326: 501-506. 
9. Sears MR, Taylor DR, Print CG, et al. Regular inhaled beta agonist treatment in bronchial asthma. Lancet 1990; 336: 1391-1396.

10. Vathenen AS, Knox AJ, Higgins BG, Britton JR, Tattersfield AE. Rebound increase in bronchial responsiveness after treatment with inhaled terbutaline. Lancet 1988; i: $554-558$.

11. van Schayck CP, Dompeling E, van Herwaarden CLA, et al. Bronchodilator treatment in moderate asthma or chronic bronchitis: continuous or on demand? A randomised controlled study. BMJ 1991; 303: 1426-1431.

12. Greening AP, Ind PW, Northfield M, Shaw G. Added salmeterol versus higher-dose corticosteroid in asthma patients with symptoms on existing inhaled corticosteroid. Lancet 1994; 334: 219-224.

13. Woolcock A, Lundback B, Ringdal N, Jacques LA. Comparison of addition of salmeterol to inhaled steroids with doubling of the dose of inhaled steroids. Am J Respir Crit Care Med 1996; 153: 1481-1488.

14. Pauwels RA, Claes-Goran L, Postma DS, et al. Effect of inhaled formoterol and budesonide on exacerbations of asthma. N Engl J Med 1997; 337: 1405-1411.

15. Gardiner PV, Ward C, Booth H, Allison A, Hendrick DJ, Walters EH. Effect of eight weeks treatment with salmeterol on bronchoalveolar lavage inflammatory indices in asthmatics. Am J Respir Crit Care Med 1994; 150: 1006-1011.

16. Chai H, Farr RS, Froelich LA, et al. Standardisation of bronchial inhalation challenge procedures. $J$ Allergy Clin Immunol 1975; 56: 323-327.

17. Djukanovic R, Wilson JW, Lai CKW, Holgate ST, Howarth PH. The safety aspects of fibreoptic bronchoscopy, bronchoalveolar lavage, and endobronchial biopsy in asthma. Am Rev Respir Dis 1991; 143: 772-777.

18. NIH workshop summary and guidelines. Investigative use of bronchoscopy, lavage, and bronchial biopsies in asthma and other airways diseases. Eur Respir J 1992; 5: $115-121$.

19. Gratziou C, Carroll M, Walls A, Howarth PH, Holgate ST. Early changes in T lymphocytes recovered by bronchoalveolar lavage after local allergen challenge of asthmatic airways. Am Rev Respir Dis 1992; 145: 1259-1264.

20. Kelly RW, Deam S, Cameron MJ, Seamark PF. Measurement by radioimmunoassay of prostaglandins as their methyl oximes. Prostaglandin Leukotr Med 1986; 24: 114.

21. Weeke B. Rocket immunoelectrophoresis. Scand $J$ Immunol 1973; 1: 37-46.

22. Britten KM, Howarth PH, Roche WR. Immunohistochemistry on resin sections, a comparison of resin embedding techniques for small mucosal biopsies. Biotech Histochem 1993; 68: 271-280.
23. Walls AF, Bennett AR, McBride HM, Glennie MJ, Holgate ST, Church MK. Production and characterisation of monoclonal antibodies specific for human mast cell tryptase. Clin Exp Allergy 1990; 20: 581-589.

24. Spurr AR. A low viscosity epoxy resin embedding medium for electron microscopy. J Ultrastruct Res 1969; 26: 31-43.

25. Djukanovic R, Wilson JW, Britten KM, et al. The inhibitory effect of the inhaled corticosteroid beclomethasone dipropionate on airway mucosal mast cell and eosinophil numbers relates to its clinical efficacy in asthma. Am Rev Respir Dis 1990; 145: 669-674.

26. Anonynous. The British guidelines on asthma management: 1995 review and position statement. Thorax 1997; 52: Suppl. 1.

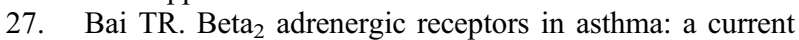
perspective. Lung 1992; 170: 125-141.

28. Church MK, Hiroi J. Inhibition of IgE-dependent histamine release from human dispersed lung mast cells by anti-allergic drugs and salbutamol. Br J Pharmacol 1987; 90: 421-429.

29. Mosberg B. Mucociliary transport and its influence by beta-adrenoceptor drugs. Acta Pharmacol Toxicol 1979; 44: 41-44.

30. Howarth PH, Durham SR, Lee TH, Kay AB, Church MK, Holgate ST. Influence of albuterol, cromolyn sodium and ipratropium bromide on the airway and circulating mediator responses to allergen provocation in asthma. Am Rev Respir Dis 1985; 132: 986-992.

31. Bradley BL, Azzawi M, Jacobson M, et al. Eosinophils, T-lymphocytes, mast cells, neutrophils, and macrophages in bronchial biopsy specimens from atopic subjects with asthma: Comparison with biopsy specimens from atopic subjects without asthma and normal control subjects and relationship to bronchial hyperresponsiveness. $J$ Allergy Clin Immunol 1991; 88: 661-674.

32. Szefler SJ, Ando R, Cicutto LC, Surs W, Hill MR, Martin RJ. Plasma histamine, epinephrine, cortisol and leukocyte $\beta$-adrenergic receptors in nocturnal asthma. Clin Pharmacol Ther 1991; 49: 59-68.

33. Cheung D, Timmers MC, Zwinderman AH, Bel EH, Dijkman JH, Sterk PJ. Long term effects of a long-acting $\beta_{2}$-adrenoceptor agonist, salmeterol, on airway hyperresponsiveness in patients with mild asthma. $N$ Engl $J$ Med 1992; 327: 1198-1203.

34. Laitinen LA, Laitinen A, Haahtela T. A comparative study of the effects of an inhaled corticosteroid, budesonide, and a $\beta_{2}$-agonist, terbutaline, on airway inflammation in newly diagnosed asthma: a randomised, double-blind, parallel-group controlled trial. J Allergy Clin Immunol 1992; 90: 32-42. 